\title{
EFFECT OF PULSED LASER ABLATION IN WATER ON THE CORROSION BEHAVIOUR AND SURFACE HARDNESS OF STAINLESS STEELS
}

\author{
(Kesan Ablasi Laser Gentian Denyut dalam Air terhadap Kakisan dan Kekerasan Permukaan \\ Keluli Kalis Karat)
}

\author{
Sze Ney Chan ${ }^{1}$, Wai Yin Wong ${ }^{2} *$, Walvekar Rashmi ${ }^{1}$, Abdul Amir Hassan Kadhum², ${ }^{2,}$ Mohammad Khalid ${ }^{4}$, \\ Kean Long Lim $^{2}$ \\ ${ }^{I}$ School of Engineering, \\ Taylor's University Lakeside Campus, Jalan Taylor's, Subang Jaya, 47500, Selangor, Malaysia \\ ${ }^{2}$ Fuel Cell Institute \\ ${ }^{3}$ Department of Chemical and Process Engineering, Faculty of Engineering and Built Environment \\ Universiti Kebangsaan Malaysia, 43600 UKM Bangi, Selangor, Malaysia \\ ${ }^{4}$ Graphene \& Advanced 2D Materials Research Group (GAMRG), \\ Sunway University, No. 5, Jalan Universiti, Bandar Sunway, 47500 Subang Jaya, Selangor, Malaysia \\ *Corresponding author: waiyin.wong@ukm.edu.my,RashmiGangasa.Walvekar@taylors.edu.my
}

Received: 13 April 2017; Accepted: 17 April 2018

\begin{abstract}
This work presents the use of pulsed fibre laser ablation in water (PLAW) to study the corrosion behaviour and surface hardness of stainless steels. A stainless-steel plate was ablated with a pulsed ytterbrium-doped fibre laser at a power of $4.2 \mathrm{~W}$. The laserablated sample was subjected to corrosion testing using electrochemical impedance spectroscopy and potentiodynamic polarisation. The results correlated with surface morphology, X-ray diffraction profiles and Vicker's hardness values. PLAW can enhance the corrosion resistance of stainless steels in both neutral and acidic electrolytes. The corrosion potential of the lasertreated samples was more positive at -126 and $-423 \mathrm{mV}$ compared with that of the as-received samples at -209 and $-439 \mathrm{mV}$ in neutral and acidic electrolytes, respectively. The inhibition efficiencies of the laser-treated samples in neutral and acidic electrolytes were $98 \%$ and $52 \%$, respectively. An improvement in the surface microhardness at a maximum of $8.7 \%$ was reported on the fibre laser-ablated stainless steels, thereby demonstrating the efficiency of fibre-laser-assisted PLAW in inhibiting corrosion and improving the hardness of stainless steel.
\end{abstract}

Keywords: stainless steel, corrosion inhibition, fibre laser, pulse laser ablation in water

\section{Abstrak}

Kajian ini bertujuan untuk mengkaji kesan penggunaan teknik ablasi laser gentian denyut dalam air terhadap kakisan dan kekerasan permukaan keluli kalis karat. Dalam kajian ini, plat keluli kalis karat telah diablasi dengan laser gentian denyutan terdop ytterbrium pada kuasa 4.2 W. Seterusnya, plat sampel ini dikaji terhadap kakisan dengan teknik spektroskopi impedans elektrokimia dan polarisasi potentiodinamik. Kajian terhadap morfologi permukaan, profil sinar-X dan kekerasan Viker juga dilakukan. Kajian menunjukkan bahawa teknik ini dapat mempertingkatkan rintangan kakisan keluli kalis karat dalam elektrolit neutral dan asid. Potensi kakisan yang lebih positif diperolehi pada sampel terablasi laser gentian, iaitu pada $-126 \mathrm{mV}$ dan -423 $\mathrm{mV}$ berbanding dengan sampel kawalan $(-209 \mathrm{mV}$ dan $-439 \mathrm{mV})$, masing-masing dalam elektrolit neutral dan asid. Kecekapan perencatan kakisan pada sampel terablasi adalah $98 \%$ dalam elektrolit neutral dan $24 \%$ dalam elektrolit asid. Sebanyak $8.7 \%$ pembaikan dari segi kekerasan mikro pada permukaan sampel terablasi dicapai. Hasil kajian ini berjaya menunjukkan kelebihan penggunaan laser gentian dalam proses ablasi keluli kalis karat dalam meningkatkan ketahanan kakisan dan kekerasan permukaan. 


\section{Chan et al: EFFECT OF PULSED LASER ABLATION IN WATER ON THE CORROSION BEHAVIOUR AND SURFACE HARDNESS OF STAINLESS STEELS}

Kata kunci: keluli kalis karat, kecekapan perencatan kakisan, laser gentian, ablasi laser denyut dalam air

\section{Introduction}

Metals are essential materials in manufacturing fields; they are used from heavy and small-medium industries to households. Stainless steels are widely used for different applications, such as kitchen utensils, structural beams, chemical vessels, outdoor usage and others, because of its outstanding mechanical and physical characteristic that can withstand harsh environment. Nonetheless, stainless steels, especially AISI 304 stainless steel, are still susceptible to corrosion, particularly due to pitting, crevice corrosion and stress corrosion cracking, when exposed to tensile stresses in a warm chloride environment. Therefore, enhancing the surface properties of the materials is highly required.

Numerous methods have been developed to prevent corrosion, such as protective coatings [1], cathodic protection [2] and corrosion inhibitor use [3]. However, these conventional methods are impractical because they require chemicals, high installation cost and maintenance and are not environmentally friendly [4]. Pulse laser ablation in liquid (PLAL) is a novel, clean and easy approach; it is marketed for its ability to modify the surface composition with high speed, low processing time and easy operation. Hence, PLAL can modify surface properties by enhancing the corrosion resistance, mechanical properties and biocompatibility of the uniform microstructures. Most studies that used this technique for surface modification have been performed using neodymium-doped yttrium aluminum garnet, $\mathrm{Nd}-\mathrm{YAG}$ laser [5], excimer laser [6] or carbon dioxide, $\mathrm{CO}_{2}$ laser [7]. Sun et al. [7] fabricated 304 stainless steel blades with chromium-chromium borides, $\mathrm{Cr}-\mathrm{CrB}_{2}$ powders by using $\mathrm{CO}_{2}$ laser to enhance the microhardness and wear performance of 304 stainless steels; they revealed that the corrosion potentials of all alloyed layers were higher $(-0.4306 \mathrm{~V})$ compared with those of non-laser treated metal $(-0.4493 \mathrm{~V})$. Yue et al. [8] modified the surface of Ti-6Al-4V alloy using excimer laser to improve the corrosion behaviour for dental applications and demonstrated that the corrosion resistance of the alloys increased by seven times from the original. Laser surface modification can inhibit wear and enhance the fatigue resistance of machine components, because it can control surface morphology up to the submicron or even at a finer depth resolution than the submicron level. Fibre laser is environmentally safe, simple, low cost and practical for use in comparative studies [9, 10].

The current study mainly emphasises on the improvement of corrosion behaviour of ASTM 304/2B stainless steel by utilising the chemical-free technique, namely, PLAL with fibre laser. Surface morphology and hardness were determined using X-ray diffraction (XRD), scanning electron microscopy (SEM) and Vickers hardness test. Electrochemical corrosion testing was conducted to determine corrosion inhibition efficiency by using electrochemical impedance spectroscopy (EIS) techniques and potentiodynamic polarisation (PDP) to study the effect of metal surface modification through PLAL on corrosion resistance.

\section{Materials}

\section{Materials and Methods}

ASTM 304/2B stainless steel with a $6 \mathrm{~cm} \mathrm{x} 4 \mathrm{~cm}$ dimension and a $1.2 \mathrm{~mm}$ thickness was the target metal that was used in this study. The composition of the metal steel is shown in Table 1 and is determined via arc-spark optical emission spectroscopy (WAS Foundry-Master, Oxford Instruments). Sodium chloride, $\mathrm{NaCl}$ (99\% purity) was obtained from R\&M Chemicals. Hydrochloric acid, $\mathrm{HCl}$ (ACS reagent, 37\%) was obtained from Sigma-Aldrich. Ethanol, $\mathrm{C}_{2} \mathrm{H}_{5} \mathrm{OH}\left(95 \%\right.$ purity) and acetone, $\mathrm{CH}_{3} \mathrm{COCH}_{3}(99.5 \%$ purity) were obtained from R\&M Chemicals for sample cleaning purposes. Alumina suspension with a particle size of $0.05 \mu \mathrm{m}$ was purchased from Buehler for metal polishing.

Table 1. Nominal chemical composition of metal used in the study (wt.\%)

\begin{tabular}{lcccccccc}
\hline Type of Metal & $\mathbf{C}$ & $\mathbf{C r}$ & $\mathbf{N i}$ & $\mathbf{S i}$ & $\mathbf{M n}$ & $\mathbf{P}$ & $\mathbf{S}$ & $\mathbf{F e}$ \\
\hline $\begin{array}{l}\text { ASTM 304/2B } \\
\text { stainless steel }\end{array}$ & 0.03 & 19.2 & 8.11 & 0.38 & 1.12 & 0.02 & $<0.005$ & 70.7 \\
\hline
\end{tabular}




\section{Sample preparation}

Metal surfaces were initially polished with silicon carbide, SiC abrasive paper (grit size 500-2000 $\mu \mathrm{m}$ ), followed by fine polishing using ASTM standard E3-11 $0.05 \mu \mathrm{m}$ alumina suspension. Acetone and ethanol were sequentially used to assist the ultrasonic cleaning on metal surfaces in a Crest 5 Gallon Heated Ultrasonic Cleaner (4HT-1014-6, Crest Ultrasonics Corp.) for 20 minutes at $50{ }^{\circ} \mathrm{C}$. Finally, the metals were air dried prior to laser ablation.

\section{Experimental set up}

Laser ablation on stainless steel was performed using a pulsed ytterbrium-doped fibre laser (YLP-1-100-20-20-HC, IPG Photonics) with a wavelength of $1064 \mathrm{~nm}$ and a pulse width of $\sim 100 \mathrm{~ns}$. The metal target was fixed on a perspex block that is immersed in water at $5 \mathrm{~mm}$ depth from the metal surface using an $800 \mathrm{~mL}$ beaker. The experimental set up is shown in Figure 1. An impact diameter of $50 \mu \mathrm{m}$ was used to ablate the metal targets. During laser ablation, an overlapping rate of $60 \%$, a scanning speed of $2000 \mathrm{~mm} / \mathrm{s}$, a power irradiation of $4.2 \mathrm{~W}$ and laser pulse number of 100000 were applied. At the end of the process, the metal surfaces were cleaned with wiper and air dried.

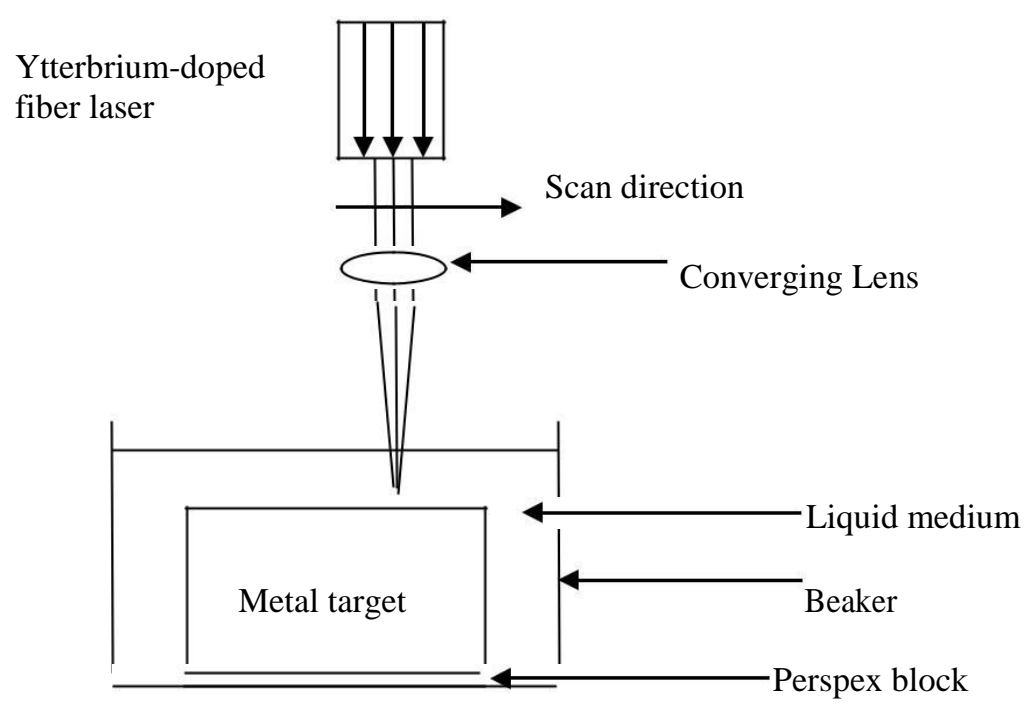

Figure 1. Schematic diagram of PLAL experiment set up

\section{Electrochemical corrosion testing}

The corrosion behaviour of the samples was studied using electrochemical testing on a potentiostat (Gamry Instrument Potentiostat/Galvanostat/ZRA model Ref. 600) that includes EIS and PDP. Two corrosion media were employed, including $3.5 \mathrm{wt} \% \mathrm{\textrm {NaCl }}[11]$ and $10 \% \mathrm{HCl}$ [12] at room temperature. A three-electrode set up was used. The sample, as the working electrodewas mounted on the cell with an exposed area of $1.0 \mathrm{~cm}^{2}$ to the electrolyte. Platinum wire and saturated calomel electrode (SCE) were used as the counter and reference electrodes, respectively. Prior to EIS measurement, the cell was switched to open-circuit-potential mode for 1 hour until potential stabilisation was achieved. EIS was performed at a frequency range of $10-0.01 \mathrm{~Hz}$ that was applied at a signal amplitude perturbation of $10 \mathrm{mV}$. PDP measurement was conducted subsequently at a potential window of $-500-500 \mathrm{mV}$ versus $\mathrm{SCE}$ and a scan rate of $0.5 \mathrm{mV} / \mathrm{s}$.

\section{Sample characterisation}

The surface morphologies and elemental composition of the metal surfaces were studied using a field-emission SEM that is equipped with an energy dispersive spectrometer (EDX) (FEI Model, Quanta 400F) with a current beam of $1.1 \mathrm{nA}$ and a beam voltage of $10 \mathrm{kV}$. A high-angle X-ray diffractometer (Bruker/D8 Advance) that is 


\section{Chan et al: EFFECT OF PULSED LASER ABLATION IN WATER ON THE CORROSION BEHAVIOUR AND SURFACE HARDNESS OF STAINLESS STEELS}

equipped with Ni-filtered $\mathrm{Cu} \mathrm{K} \alpha$ radiation with an accelerating voltage of $40 \mathrm{kV}$ and a current of $40 \mathrm{~mA}$ was used to study the crystallographic structure on the sample surfaces. The grazing incidence technique was used. Microhardness tests were performed using a Vickers hardness tester (Mitutoyo, Model HM-210) to determine the microhardness in accordance with the ASTM B931-03 standard. The hardness of the as-received and laser-treated samples were determined by pressing an indenter onto the sample with a controlled test force $F$ of $2 \mathrm{~N}$ and a dwell time of $10 \mathrm{~s}$. The size of the indentation was optically determined by measuring two diagonals $d$ of the square indentation with a microscope as an integral part of a Vickers tester. Five measurements were obtained for each sample, and the average value of the Vickers number (Hv) was calculated based on equation 1 [13], as follows:

$$
\text { Vickers hardness }=1.844 \mathrm{~F} / d^{2}\left(\mathrm{kgf} / \mathrm{mm}^{2}\right)
$$

\section{Corrosion behaviour in $\mathrm{NaCl}$ and $\mathrm{HCl}$ solutions}

\section{Results and Discussion}

Figure 2 presents the Nyquist plots for the samples immersed in 3.5 wt. $\% \mathrm{NaCl}$ and $10 \% \mathrm{HCl}$, which represent neutral and acidic media, respectively. Both Figure 2 (a) and (b) illustrate capacitive loops even though Figure 2(a) shows an incomplete loop because of the high corrosion resistance of stainless steel towards a neutral medium. The presence of capacitive loop indicates that the corrosion of the stainless steel was mainly controlled by a charge transfer process, which is due to the dielectric nature of the metal oxide film on the surface [14]. In both media, laser-treated samples displayed larger capacitive loop compared with the as-received samples. Thus, the improved corrosion resistance is achieved upon laser treatment. Nonetheless, the Nyquist plot obtained in the neutral $\mathrm{NaCl}$ medium (Figure 2(a)) did not show perfect semicircles because stainless steel naturally shows higher resistance in the less corrosive neutral medium than in acidic medium. In the acidic medium, complete semicircles were obtained (Figure 2(b)) for both laser-treated and untreated samples. A good time constant (RC) behaviour was recorded at high frequency, which was attributed to the capacitive behaviour of stainless steel. This characteristic was accompanied by inductive behaviour at low frequency. This inductive loop is evident in other studies on metal corrosion in acid, mainly due to the slow changes in the surface microstructures of the samples because of the breakdown of passivation film upon corrosion. The different corrosion behaviours in neutral and acidic media were studied from the impedance and Bode plots (Figure 3). In neutral medium, two RCs were detected from the Bode plots, as shown by two continuous capacitive arcs, indicating the presence of layers of oxide film covering the sample surface. The interfacial processes in the $\mathrm{NaCl}$ electrolyte were modelled using the equivalent circuit fitting. The data are displayed in Table 2. The components in the equivalent circuit fitted in $\mathrm{NaCl}$ electrolyte include the film resistance $\left(R_{f}\right)$, electrolyte resistance $\left(R_{s}\right)$ and the constant phase element of the surface layer (CPE1). The parameter group $\left(\mathrm{R}_{\mathrm{ct}}-\mathrm{CPE} 2\right)$ offers data on the mass transport during corrosion attack and charge transfer reaction through the oxide films, representing the capacitance of the double layer and charge transfer resistance, respectively. The increase in Rct values upon laser treatment indicates that the diffusion of ions into the micropores of the oxide film was reduced due to the large resistance to charge transfer, that is, Rf on the film surface.

In acidic medium, only one RC was displayed in the Bode plots, which may be attributed to the less significant effect of the oxide film. This film acts as a protective barrier for corrosion. Hence, the RC also correlated with the Nyquist plots, where much smaller capacitive loops were obtained in a harsh environment. The appearance of the inductive loop also indicated changes in the specimen properties during the corrosion process. The components in the equivalent circuit that was fitted for the $\mathrm{HCl}$ solution include the solution resistance $\left(\mathrm{R}_{\mathrm{s}}\right)$, charge transfer resistance $\left(\mathrm{R}_{\mathrm{ct}}\right)$, constant phase element of double layer $\left(\mathrm{CPE}_{\mathrm{dl}}\right)$ and the inductance parallel with resistance (Figure 2(b)). Herein, we investigated corrosion resistance using the obtained charge transfer resistance. The $\mathrm{R}_{\mathrm{ct}}$ values obtained on the laser sample showed insignificant improvement of corrosion resistance. In the circuit fitting, the CPE component was used because of the non-ideal capacitive behaviour of the system, in which the surface of the samples was expected to be non-uniform [15]. The impedance of CPE is shown in equation 2 [16], as follows:

$$
\mathrm{ZCPE}=\mathrm{Y}_{0}^{-1}(j w)^{-n}
$$

where $\mathrm{Y}_{0}$ represents the magnitude of the CPE, and $n$ is an exponential term between 0 and 1 . The variation of $n$ is dependent on the surface roughness of the surface. $n$ varied between 0 and 1 for a corrosion system. 


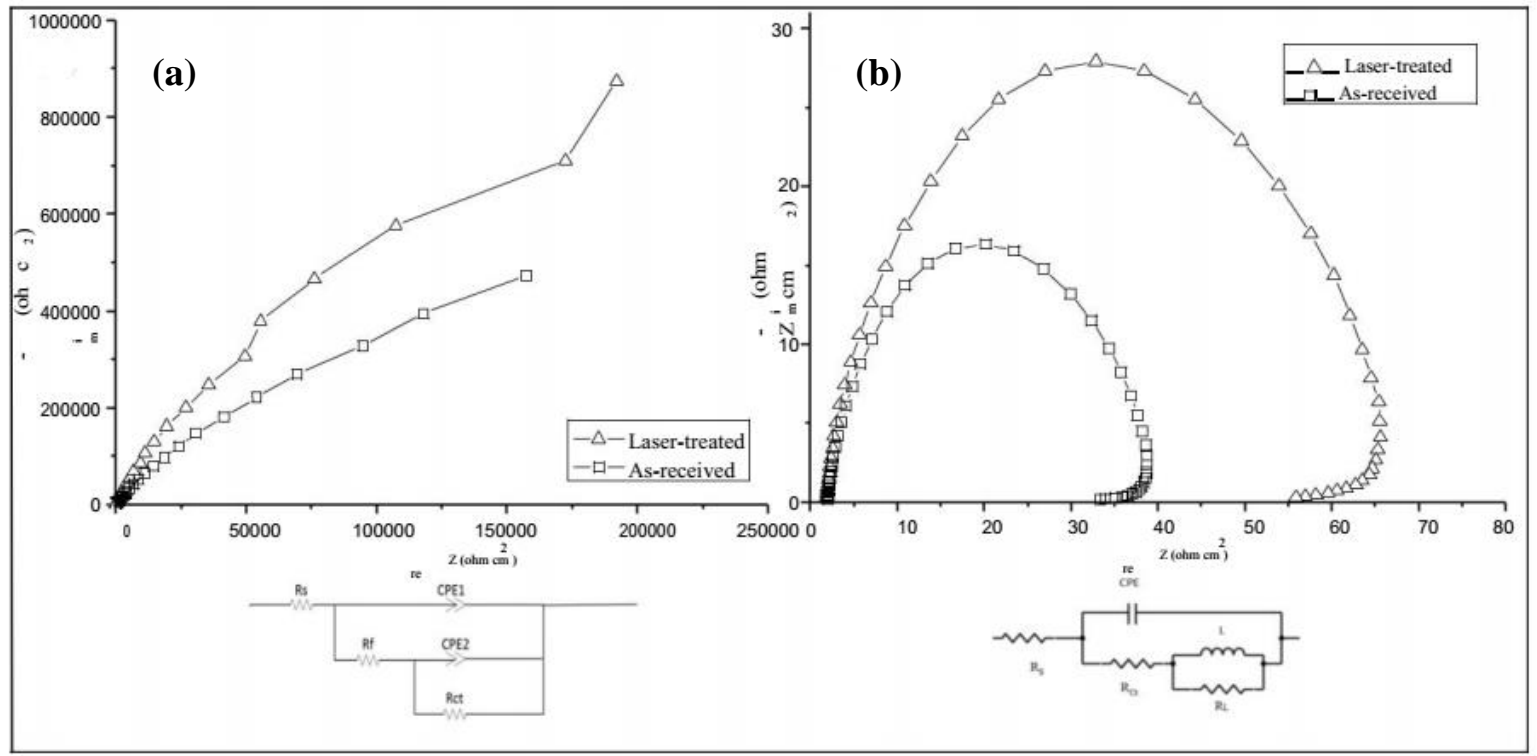

Figure 2. Nyquist plots from impedance spectroscopy for laser treated and as-received stainless steel in (a) 3.5 wt. $\% \mathrm{NaCl}$ solution and (b) $10 \% \mathrm{HCl}$ solution with equivalent circuit model

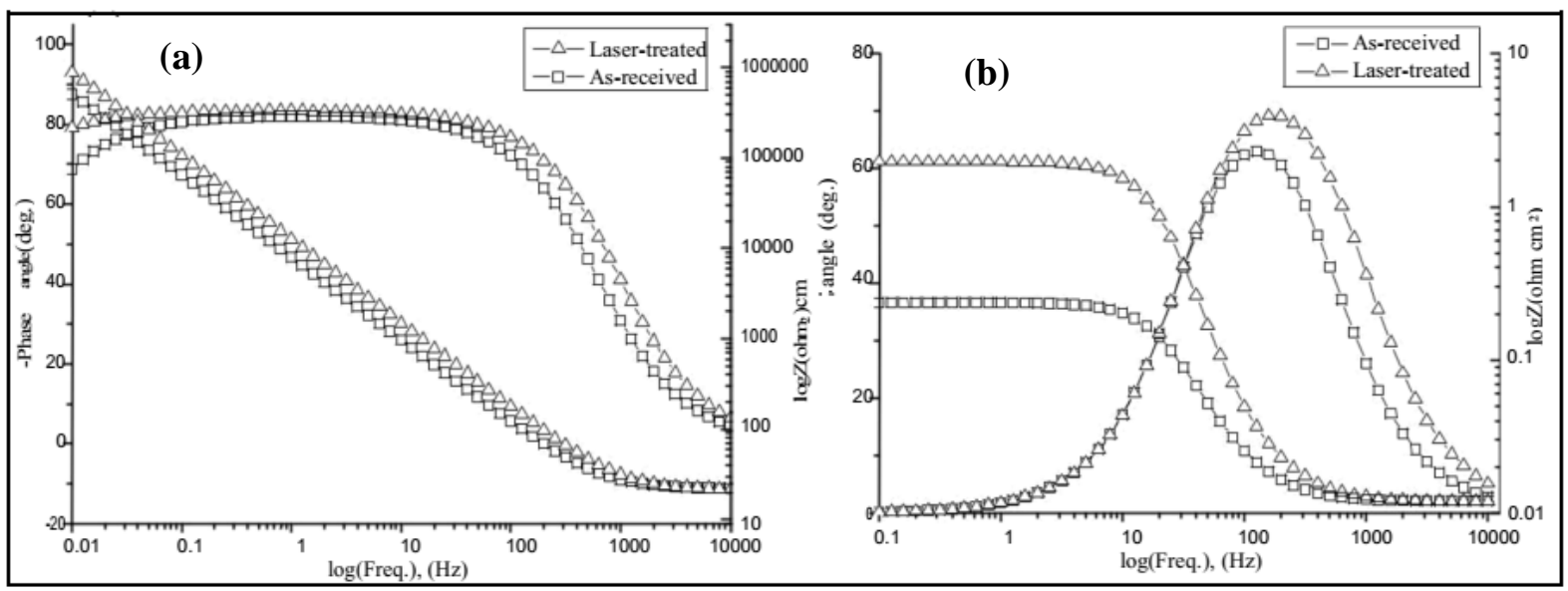

Figure 3. The experimental impedance and phase data in Bode format for stainless steel in (a) $3.5 \mathrm{wt} . \% \mathrm{NaCl}$ solution and (b) $10 \% \mathrm{HCl}$ solution and equivalent circuits to fit the impedance data

The inhibition efficiency (I.E.\%) was calculated based on equation 3 [17].

$$
\text { I.E. } \%=\left(\mathrm{R}_{\mathrm{ct}}-\mathrm{R}_{\mathrm{ct}}^{\mathrm{o}}\right) / \mathrm{R}_{\mathrm{ct}} \mathrm{x} 100 \%
$$

where $\mathrm{R}_{\mathrm{ct}}$ and $\mathrm{R}_{\mathrm{ct}}^{\mathrm{o}}$ are the charge-transfer resistance that were obtained from the circuit fitting with respect to lasertreated and as-received samples, respectively. 


\section{Chan et al: EFFECT OF PULSED LASER ABLATION IN WATER ON THE CORROSION BEHAVIOUR AND SURFACE HARDNESS OF STAINLESS STEELS}

Table 2. Electrochemical impedance parameters and inhibition efficiency of stainless steel in $3.5 \mathrm{wt} . \% \mathrm{NaCl}$ and $10 \% \mathrm{HCl}$ solutions

\begin{tabular}{lcccccc}
\hline Sample & $\mathbf{R}_{\mathrm{f}}$ & $\mathbf{R}_{\mathrm{s}}$ & $\mathrm{CPE} 1 / \mathrm{CPE}_{\mathrm{dl}} / \mathbf{n}$ & $\mathrm{CPE} 2 / \mathbf{n}$ & $\mathbf{R}_{\mathrm{ct}}$ & I.E.\% \\
& $\left(\Omega \mathrm{cm}^{1}\right)$ & $\left(\Omega \mathrm{cm}^{1}\right)$ & $\mathrm{Y0}\left(\Omega^{-1} \mathrm{~cm}^{-2}\right)$ & $\mathrm{Y0}\left(\Omega^{-1} \mathrm{~cm}^{-2}\right)$ & $\left(\Omega \mathrm{cm}^{1}\right)$ & \\
\hline
\end{tabular}

\begin{tabular}{lccccccc}
\multicolumn{2}{l}{ Stainless Steel in 3.5 wt.\% NaCl Solution } \\
\hline Laser treated & $1.18 \times 10^{7}$ & 21.31 & $1.45 \times 10^{-5} / 0.93$ & $1.50 \times 10^{-2} / 0.96$ & $1.58 \times 10^{6}$ & 98.73 \\
As-received & $2.13 \times 10^{6}$ & 21.88 & $2.33 \times 10^{-5} / 0.92$ & $9.22 \times 10^{4} / 0.27$ & $2.00 \times 10^{4}$ & - \\
\hline
\end{tabular}

Stainless Steel in $10 \%$ HCl Solution

\begin{tabular}{lcccccc}
\hline Laser treated & - & 1.86 & $1.59 \times 10^{-4}$ & - & 61.96 & 51.88 \\
As-received & - & 1.96 & $2.89 \times 10^{-4}$ & - & 29.81 & - \\
\hline
\end{tabular}

In both solutions, the value of $\mathrm{R}_{\mathrm{ct}}$ of laser-treated sample appeared to be larger than the as-received sample, which contributed to the increase in the inhibition efficiency. The increased $R_{c t}$ value that was observed on the lasertreated sample signified the improved resistance of the metal surface to electrochemical reaction. The surfacemodified layer can restrict chemical reaction between metal surface and corrosive medium [16]. The improvement in corrosion resistance was shown to be more apparent in the less corrosive $\mathrm{NaCl}$ environment. Behpour et al. [18] reported that the maximum I.E.\% of 304 stainless steel corrosion in $2 \mathrm{M} \mathrm{HCl}$ solution by a Ferula gumosa (galbanum) extract obtained from $90.7 \%$ at 1000 ppm of galbanum extract. In the current study, the highest I.E.\% of laser-treated stainless steel in $3.5 \mathrm{wt} \% \mathrm{NaCl}$ was $98.7 \%$, which displayed similar efficiency with the abovementioned study.

Figure 4 depicts the PDP of laser-treated and as-received samples in $3.5 \mathrm{wt} . \% \mathrm{NaCl}$ and $10 \% \mathrm{HCl}$ at $25^{\circ} \mathrm{C}$. Lasertreated samples showed slightly lower anodic and cathodic potential compared with the as-received sample, illustrating an enhancement in corrosion resistance. This finding may be associated with the presence of protective film, and previous studies have also shown that fine particles of chromium oxide $\left(\mathrm{Cr}_{2} \mathrm{O}_{3}\right)$ can be formed when stainless steel is irradiated by laser [19]. Active-passive transitions were particularly observed from the appearance of shoulder at a potential that is exhibits increased positivity to the concerning corrosion potential values in neutral medium. This existence of shoulder indicated the occurrence of a passivation process due to the formation of the oxide layers. This phenomenon is not observed in the acidic medium, which is in good agreement with the obtained impedance results.

The corrosion potential $\left(\mathrm{E}_{\text {corr }}\right)$, corrosion current density $\left(\mathrm{I}_{\text {corr }}\right)$ and pitting potential $\left(\mathrm{E}_{\text {pit }}\right)$ extracted from the polarisation curves are tabulated and shown in Table 3. Notably. the laser-treated sample featured an improved corrosion behaviour compared with the as-received sample. The laser-treated sample exhibited a shift in Ecorr towards a noble direction, and the value of Icorr decreased conversely. Thus, the corrosion resistance of stainless steel is confirmed to be improved after pulse fibre laser ablation in water (PLAW) treatment. This finding correlate with the EIS results, in which laser-treated sample showed a more positive corrosion potential compared with the as-received samples in both corrosive media. Shadangi et al. [20] reported that laser-shock-peened interstitial free steel exhibited increased positive corrosion potential. This improvement in corrosion resistance after laser treatment may be attributed to the changes in microstructure and chemical composition. Furthermore, this laser treatment led to a solid solution strengthening effect, refined microstructure and increased $\mathrm{Cr}$ content that is found in stainless steel. Hence, an increasingly homogeneous distribution of $\mathrm{Cr}$ in stainless steel sample can be found because of laser treatment with overlapped pulse geometry, which offers an adequate barrier against corrosion. This finding will be discussed in the latter section. 


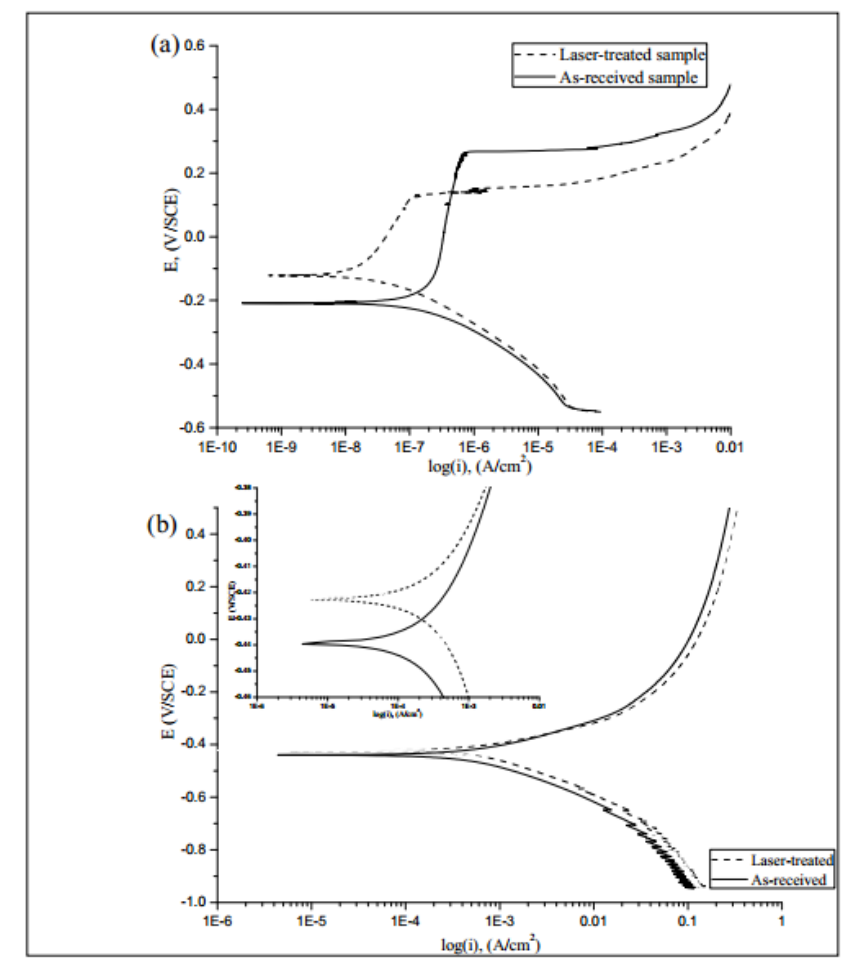

Figure 4. Polarisation curves of the samples immersed in (a) 3.5 wt.\% $\mathrm{NaCl}$ solution and (b) $10 \% \mathrm{HCl}$ solution with the blank and laser treated sample; and the inset shows the magnified Tafel region of the polarisation curve

Table 3. The results of potentiodynamic corrosion test of stainless steel in $3.5 \mathrm{wt} . \% \mathrm{NaCl}$ and $10 \% \mathrm{HCl}$ solution

\begin{tabular}{|c|c|c|c|c|c|}
\hline \multirow[t]{2}{*}{ Sample } & \multicolumn{3}{|c|}{3.5 wt. $\%$ NaCl Solution } & \multicolumn{2}{|c|}{$10 \%$ HCl Solution } \\
\hline & $\begin{array}{c}\text { Corrosion } \\
\text { Potential, } E_{\text {corr }} \\
(\mathbf{m V})\end{array}$ & $\begin{array}{c}\text { Pitting Potential, } \\
\mathbf{E}_{\text {pit }}(\mathbf{m V})\end{array}$ & $\begin{array}{c}\text { Corrosion } \\
\text { Current } \\
\text { Density, } I_{\text {corr }} \\
\left(\mu \mathbf{A} / \mathbf{c m}^{2}\right)\end{array}$ & $\begin{array}{c}\text { Corrosion } \\
\text { Potential, } \mathbf{E}_{\text {corr }} \\
(\mathrm{mV})\end{array}$ & $\begin{array}{c}\text { Corrosion } \\
\text { Current } \\
\text { Density, } \mathbf{I}_{\text {corr }} \\
\left(\mathbf{m A} / \mathbf{c m}^{2}\right)\end{array}$ \\
\hline Laser treated & -126 & 245.1 & 48.30 & -423 & 1.47 \\
\hline As-received & -209 & 259.7 & 53.80 & -439 & 2.52 \\
\hline
\end{tabular}

A decreased corrosion current density implies a decreased corrosion rate. The laser-treated sample in $\mathrm{NaCl}$ solution exhibits a slightly lower $\mathrm{I}_{\text {corr }}$ than the as-received sample, thereby indicating that laser-treated samples are more unsusceptible to corrosion in neutral solution than untreated samples. The $\mathrm{E}_{\text {corr }}$ value of laser-treated sample was more positive at $83 \mathrm{mV}$ higher than the as-received stainless steel in $\mathrm{NaCl}$ solution. Lu et al. [21] found that the $\mathrm{E}_{\text {corr }}$ of laser shot-peened stainless steel shifts to an increasingly noble direction from $-790 \mathrm{mV}$ to $-656 \mathrm{mV}$ in $\mathrm{NaCl}$ solution, which is in good agreement with our results. The $\mathrm{E}_{\mathrm{pit}}$ of the as-received and laser-treated samples was 259.7 and $245.1 \mathrm{mV}$, as detected in the neutral medium. This finding was mainly attributed to the overlapping geometry that ablated on the sample surface, which altered the microstructure and chemical composition of the steel. An increased $\mathrm{E}_{\mathrm{pit}}$ of the laser-treated sample indicates a decrease in sensitivity towards corrosion. Hence, the laser-treated sample poses increased corrosion resistance. 


\section{Chan et al: EFFECT OF PULSED LASER ABLATION IN WATER ON THE CORROSION BEHAVIOUR AND SURFACE HARDNESS OF STAINLESS STEELS}

Similarly, the $\mathrm{E}_{\text {corr }}$ of laser treated sample shifted to a more noble value compared with the as-received sample in $\mathrm{HCl}$ solution at approximately $16 \mathrm{mV}$ more positive than the original stainless steel. This finding indicated an improvement of stainless steel with passivation ability even in extreme corrosive condition, though the improvement is less apparent in $\mathrm{HCl}$ solution compared with that in neutral medium. As reported by Wang et al. [15], the $\mathrm{E}_{\text {corr }}$ that is obtained with laser-treated stainless steel substantially exceeds values of $-504 \mathrm{mV}$. Nonetheless, the method of corrosion protection that was implemented in the study was cathodic protection, where 304 stainless steels were coupled with $\mathrm{CdTe} / \mathrm{TiO}_{2}$ electrode. Hence, this surface modification method can also offer comparative result with common corrosion protection methods, considering that the corrosion potential of laser-treated stainless steel in this work is almost at the same range $(-480-402 \mathrm{mV})$ as that in previous reports on heptamolybdate ions as corrosion inhibitor on stainless steel under almost similar experimental conditions ( -480 $402 \mathrm{mV}$ ) [22].

\section{XRD analysis}

Figure 5 shows the XRD profiles of the as-received and PLAW-treated samples. The diffraction peaks show the presence of $\alpha$-Fe (ferrite phase), as indicated by the peaks at $44.88^{\circ}, 65.5^{\circ}$ and $83.1^{\circ}$, the $\gamma$-Fe (austenite phase) at $92^{\circ}$ and martensitic at $99^{\circ}$ in the as-received sample.

Interestingly, the $\alpha$-Fe peak at $44.88^{\circ}$ in as-received sample disappeared after PLAW treatment. The peak from $44.88^{\circ}$ to $44.08^{\circ}$ slightly shifted after the laser treatment, indicating the formation of a $\gamma$-Fe peak upon laser treatment. $\gamma$-Fe is usually found as a result of rapid cooling during laser treatment, which is in good agreement with the results of Song et al. [23]. This occurrence is possibly attributed to the quenching effect on the metal surface immediately after laser ablation on the metal surface, thereby causing a change in the phase. Intensity at $67^{\circ}$ also increased upon laser ablation, which is attributed to the increase in the surface metal oxide composition of $\mathrm{Cr}_{2} \mathrm{O}_{3}[24,25]$. Upon laser ablation, $\mathrm{Cr}$ may chemically react with $\mathrm{O}$ to form a passive film of hydrated $\mathrm{Cr}_{2} \mathrm{O}_{3}$, which is highly adherent and resistant to chemical attack [24]. Whenever the passive film is damaged, passivation immediately occurs [26]. The $\mathrm{Cr}_{2} \mathrm{O}_{3}$ that are present in laser-treated stainless steels isolate metal from the corrosive environment, thereby retarding corrosion. This process may be a possible reason for the enhanced corrosion resistance of stainless steel under potentiodynamic polarisation measurement. The ferrite network restricted the indepth growth of pits because of the high $\mathrm{Cr}$ content in the austenite stainless steel and decreased the number of MnS inclusions, which are known to be the common sites for corrosion pit initiation.

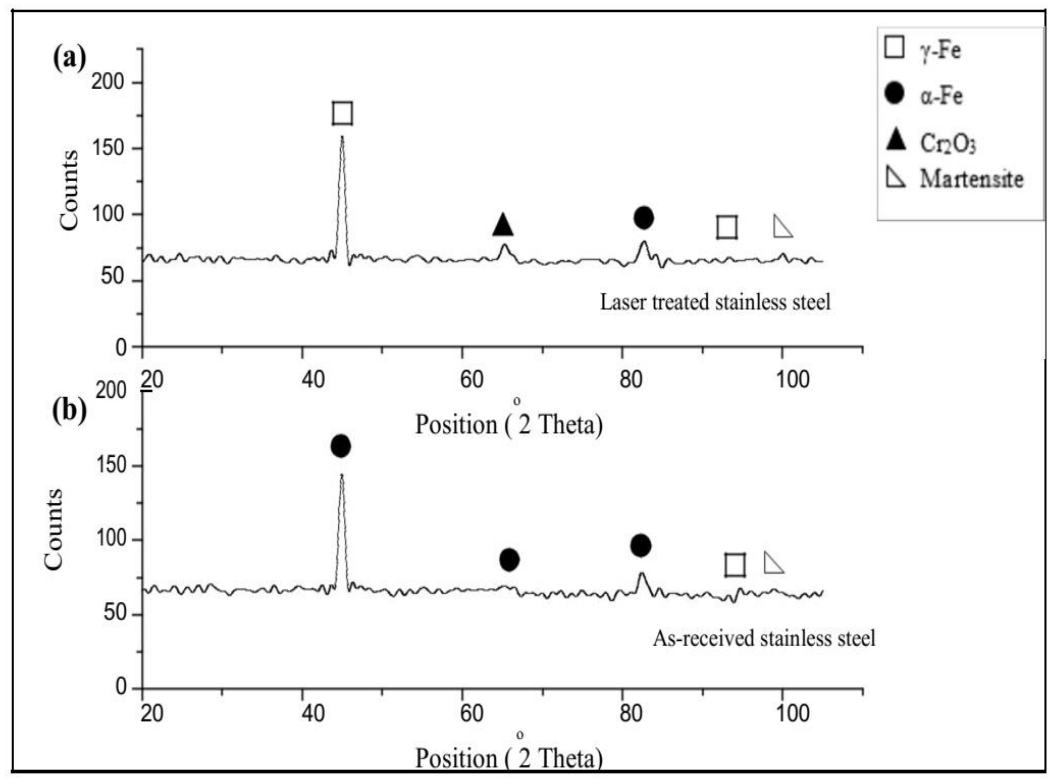

Figure 5. X-ray diffraction profiles of (a) laser treated stainless steel and (b) as-received sample 


\section{Surface morphology analysis}

Figures 6 and 7 show the SEM images and distribution maps of the major elements of laser-treated and as-received stainless steels. The EDX analysis of laser treated and as-received sample before corrosion is presented in Table 5. The elemental mapping showed the homogeneous distribution of $\mathrm{Fe}, \mathrm{O}, \mathrm{Cr}$ and $\mathrm{Mn}$. The image reveals that the microstructure patterns are consistent with the distribution of the major elements. Uniform chemical composition in the laser-treated area (Figure 6) proved that rapid solidification occurred due to high cooling rate during PLAW treatment. This high cooling rate refined the grain structures. The EDX mapping showed that the $\mathrm{Cr}$ and $\mathrm{O}$ particles that were evenly distributed over the surface on the laser-treated sample were slightly larger (Figure 8) than those in the as-received sample. Thus, the elemental composition on the surface comprised great amounts of $\mathrm{Cr}$, possibly due to the laser treatment effect. This explanation was confirmed by the XRD results, which showed an increase in the intensity of the $\mathrm{Cr}_{2} \mathrm{O}_{3}$ peak on the laser-treated sample. This finding was also correlated with the EIS results, which revealed that laser-treated samples were less prone to corrosion.
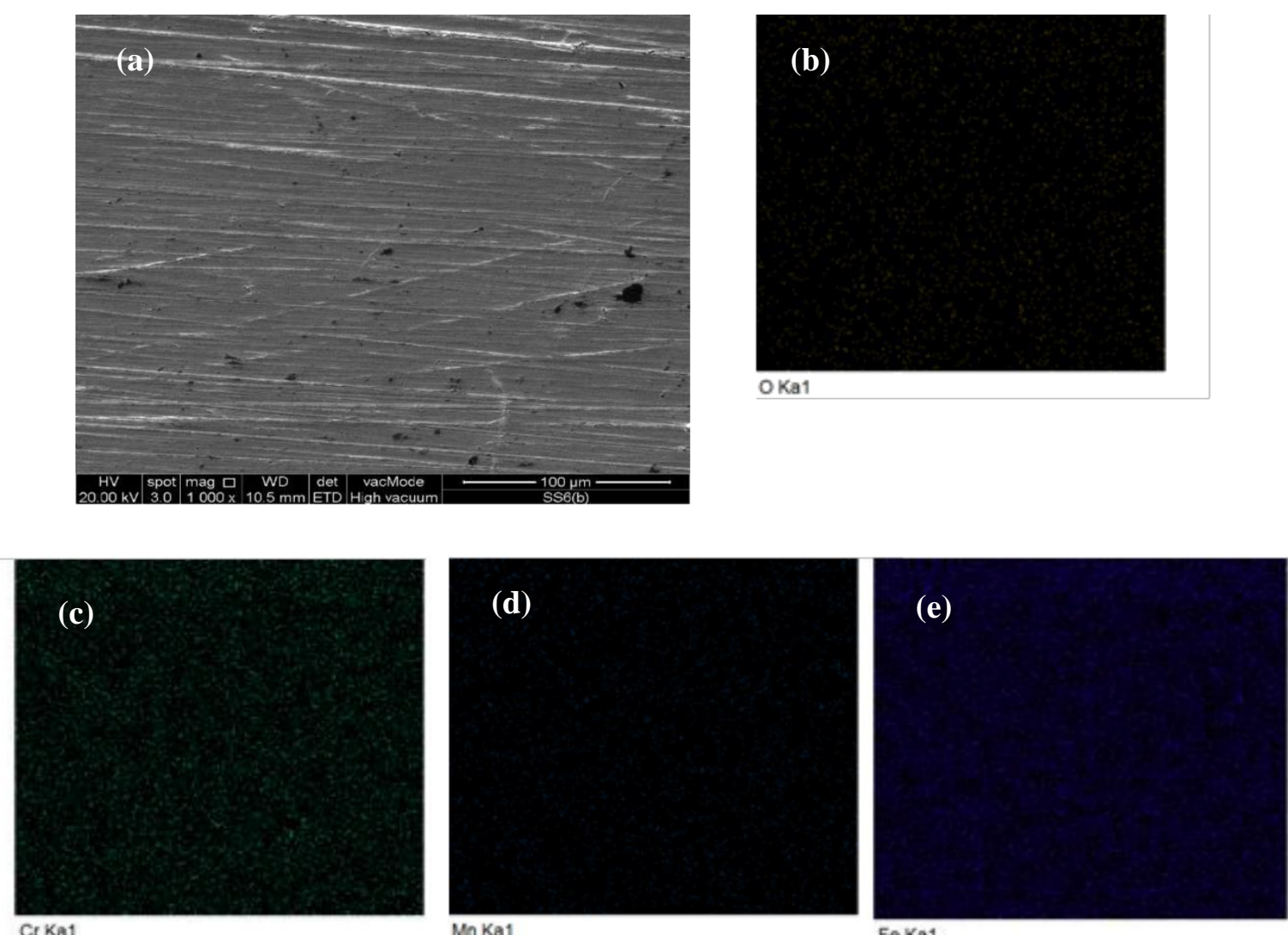

CrKa1 Mn Ka1

Figure 6. SEM image and distribution of major elements of laser treated sample before corrosion process: (a) SEM image; (b) the distribution map of $\mathrm{O}$; (c) the distribution map of $\mathrm{Cr}$; (d) the distribution map of $\mathrm{Mn}$; (e) the distribution map of $\mathrm{Mn}$ and (f) the distribution map of $\mathrm{Fe}$ 

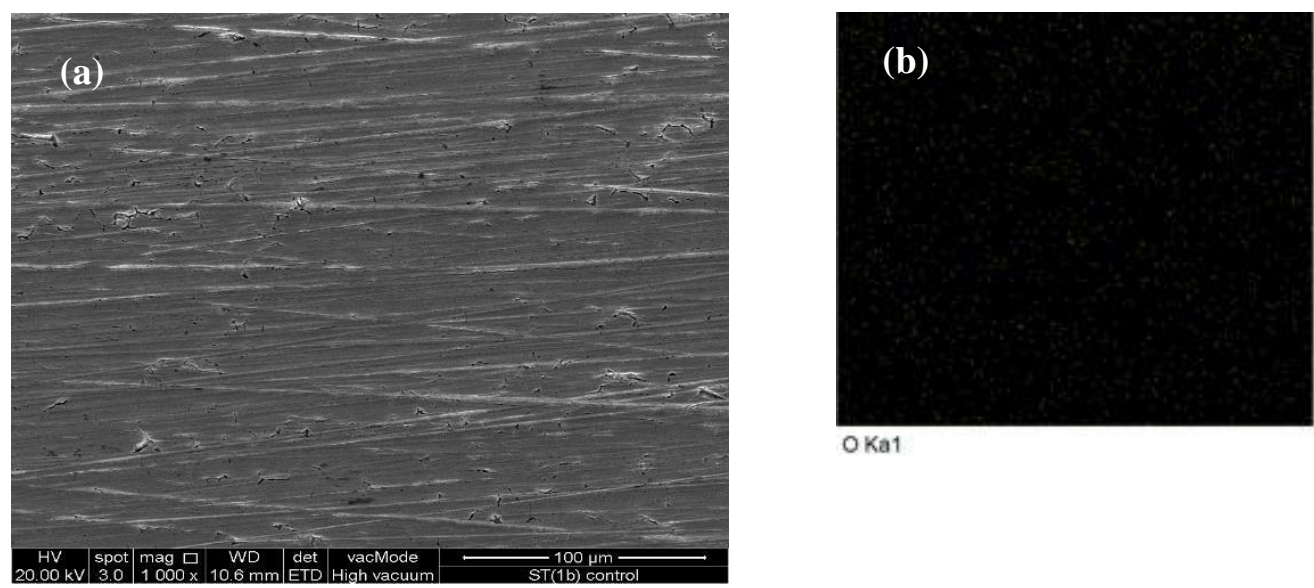

OKa1
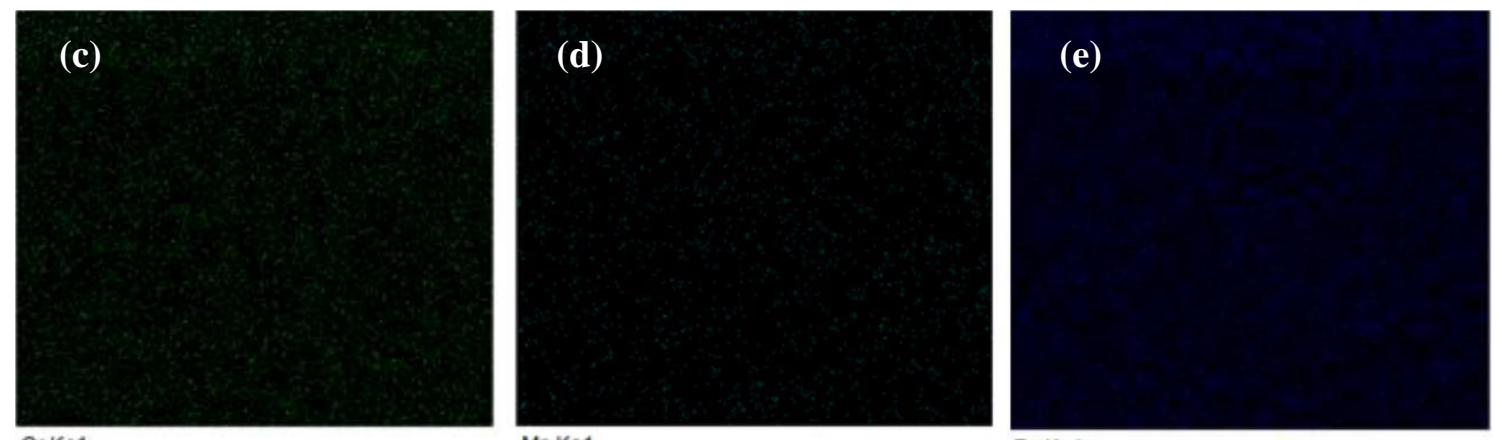

Figure 7. SEM image and distribution of major elements of as-received sample before corrosion process: (a) SEM image; (b) the distribution map of $\mathrm{O}$; (c) the distribution map of $\mathrm{Cr}$; (d) the distribution map of $\mathrm{Mn}$; (e) the distribution map of $\mathrm{Mn}$ and (f) the distribution map of $\mathrm{Fe}$

Figure 8 shows the surface morphologies and EDX spectrum of stainless steel samples that were immersed in $\mathrm{NaCl}$ solution after PDP measurement. Severe corrosive attack was observed on the as-received sample in $\mathrm{NaCl}$ solution, as shown by the strongly damaged surface due to pit formation and deformation (Figure 8(a)). Individual corroded pits clustered together and extended the area of corrosion attack. By contrast, the size of the pits on the laser-treated surface was relatively small. Moreover, the as-received sample showed high roughness and irregularity. Slight changes were observed in the surface morphology of the laser-treated sample, which has been subjected to only $4.2 \mathrm{~W}$ of power irradiation and allows less formation of refined grain structure in the laser-modified region.

EDX analysis in Figure 8 and Table 4 shows a little increment in oxide content on the laser-treated sample after corrosion compared with that of the untreated sample. EDX analysis showed that PLAW treatment seemed to result in the formation or thickening of the oxide film on the stainless steel, which increased the corrosion protective ability of stainless steel. Laser treatment on the stainless steel surface was suspected to lead to the refined microstructures through $\mathrm{Cr}$ content increase and solid solution strengthening. Hence, PLAW treatment is postulated to produce a homogeneous passive film of hydrated $\mathrm{Cr}_{2} \mathrm{O}_{3} \cdot \mathrm{Cr}_{2} \mathrm{O}_{3}$ is commonly known as a protective metal oxide that is adherent and acts as a barrier against chemical attack [27]. The higher $\mathrm{Cr}$ content by 0.9 wt.\% in the lasertreated sample (Figure 9(b)) relative to the as-received sample accounts for the less corroded morphology compared with the severely corroded morphology (Table 4). Figure 9 depicts the surface morphologies and EDX spectrum of samples immersed in $\mathrm{HCl}$ solution after PDP measurement. The EDX analysis shown in Figure 9 and Table 4 corresponds to the element distribution, which explains the appearance of few chromium and oxygen signals owing to the overlap geometry that ablated on the stainless steel surface. Thus, a continuous chromium-rich oxide layer 
was internally formed. Upon laser treatment, chromium may react with oxygen to form a protective film, $\mathrm{Cr}_{2} \mathrm{O}_{3}$, which can hinder chemical attack. This behaviour reflects the effectiveness of PLAW treatment on the corrosion resistance of stainless steel in a corrosive environment. This finding is in good agreement with the electrochemical measurement results that were previously discussed.

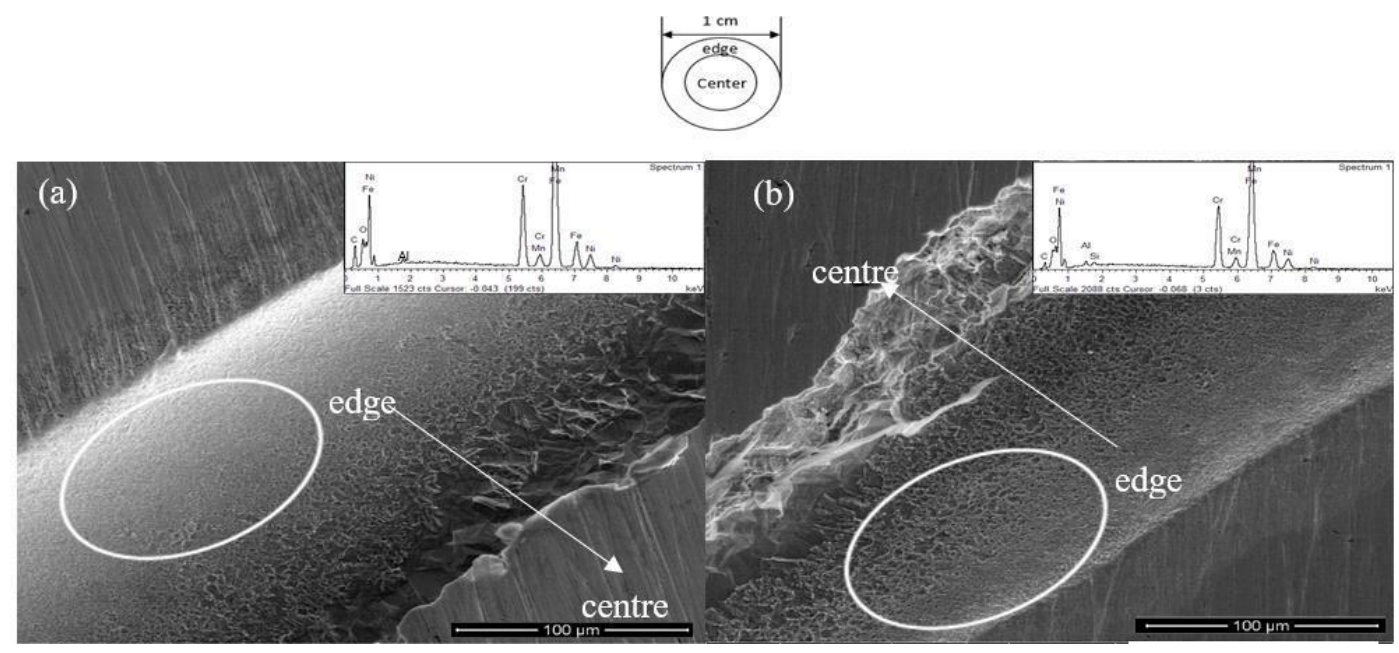

Figure 8. Corroded edge surface of the (a) laser treated and (b) as-received sample with relevant EDX result respectively after immersion in $\mathrm{NaCl}$ solution for 1 hour

Table 4. EDX analysis of laser treated and as-received samples before and after corrosion process with respective weight (wt.\%)

\begin{tabular}{lccccccccc}
\hline Sample & \multicolumn{1}{c}{ Weight (wt.\%) } \\
\cline { 2 - 10 } & $\mathbf{C}$ & $\mathbf{O}$ & $\mathbf{C r}$ & $\mathbf{M n}$ & $\mathbf{F e}$ & $\mathbf{N i}$ & $\mathbf{A l}$ & $\mathbf{S i}$ \\
\hline Before corrosion process & 6.09 & 1.62 & 17.24 & 1.21 & 65.82 & 7.24 & 0.33 & 0.45 \\
Laser treated sample & 6.02 & 2.12 & 17.18 & 1.19 & 65.70 & 6.88 & 0.46 & 0.44 \\
As-received stainless steel & & & & & & & & \\
After corrosion process (NaCl solution) & 14.03 & 4.04 & 18.17 & 1.19 & 55.26 & 6.67 & 0.64 & - \\
Laser treated sample & 6.07 & 2.65 & 17.27 & 1.43 & 64.61 & 6.79 & 0.68 & 0.48 \\
As-received stainless steel & & & & & & & & \\
After corrosion process (HCl solution) & 9.75 & 1.59 & 19.12 & 1.50 & 60.44 & 7.10 & - & 0.50 \\
Laser treated sample & 5.36 & 1.93 & 17.53 & 1.44 & 66.03 & 7.25 & - & 0.44 \\
As-received stainless steel & & & & & & & &
\end{tabular}




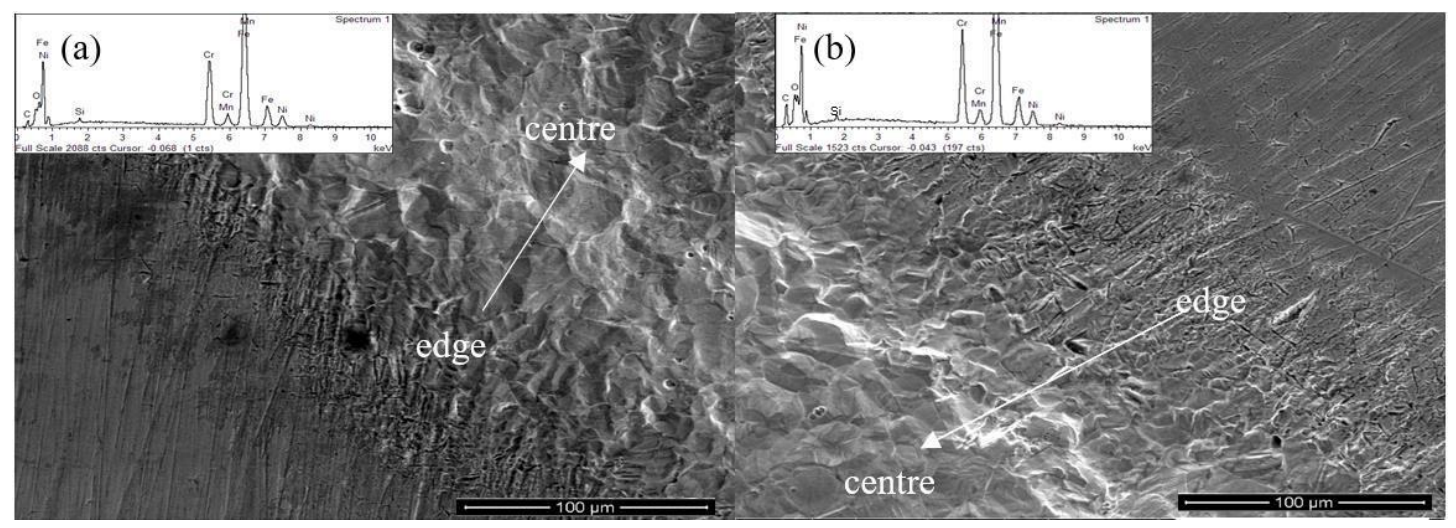

Figure 9. Corroded edge surface of the (a) laser treated and (b) as-received sample with relevant EDX result respectively after immersion in $10 \% \mathrm{HCl}$ solution for 1 hour

The analyses demonstrated that laser treatment prominently improved the corrosion resistance of stainless steel without the use of coating or the addition of a corrosion inhibitor. This improvement is possibly associated with one major reason - a chemical reaction occurred on the metal surface, which resulted in metal oxide formation that passivated the corrosion and hardened the metal surface.

\section{Vickers hardness test}

Vickers hardness test was performed for the as-received and laser-treated stainless steel. Currently, limited works have reported on the relationship between metal corrosion resistance characteristics and metal hardness. Solid solution formation upon surface modification processes, such as laser treatment, strengthens the effect of mechanical strength can hence provide some insight on corrosion behaviour. The mean of microhardness of the stainless steel as a function of depth is illustrated in Figure 10. The microhardness of laser-treated sample increases and then continuously decline along the depth from the surface. The surface microhardness $(196.94 \mathrm{Hv})$ of lasertreated sample was slightly improved by $8.7 \%$ from the as-received sample $(181.2 \mathrm{Hv})$. This finding can be attributed to the martensite formation on the surface, and the hardness was significantly higher than the core original material due to the rapid cooling effect of the PLAL treatment [28]. This gradual enhancement was only apparent at $<400 \mu \mathrm{m}$ depth from the surface. The microhardness profile demonstrated that the hardness value reached its maximum only at a $100 \mu \mathrm{m}$ depth from the surface. PLAW only induced slight work hardening due to low heating and high cooling rate on the surface. Hence, the microhardness only showed evident improvement at the upper layer of the stainless steel. This finding may also be due to the presence of coarse microstructure in the laser-treated sample because of the high cooling and low heating rate that were regulated from the PLAW treatment using ultrapure water as a liquid medium. The microstructure of the laser-treated layer did not considerably change after subsequent laser ablation process in the PLAW treatment, and hence, the improvement in microhardness was not noteworthy. However, this slight improvement of microhardness can be attributed to the compressive residual stress that was induced by PLAW treatment, which increased the yield strength and surface microhardness in the nearsurface layer of the stainless steel. 


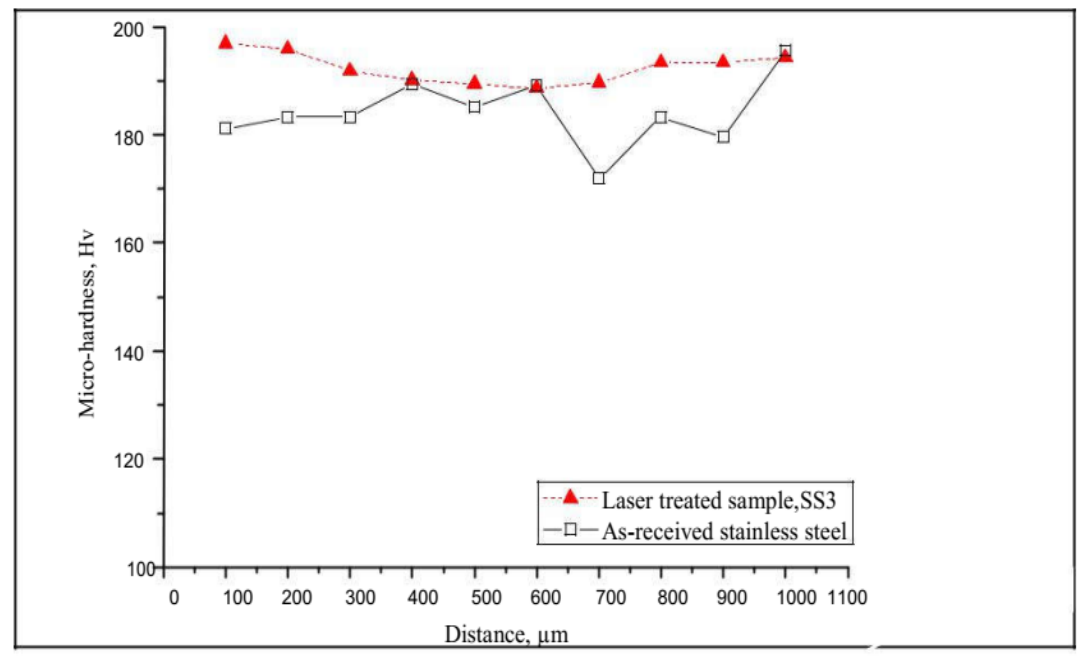

Figure 10. Microhardness profile as a function of depth from the surface on the cross-sectional plane of stainless steel sample

\section{Conclusion}

In this study, ASTM 304/2B stainless steel was subjected to PLAL treatment using fibre laser to study the effect of the treatment on corrosion resistance and surface and hardness properties of the steel. The influence of corrosion resistance on the surface modification revealed that stainless steel showed significant improvement, as evidenced by the $83 \mathrm{mV}$ higher Ecorr value from that of the as-received sample and $98 \%$ inhibition efficiency in $3.5 \mathrm{wt} . \% \mathrm{NaCl}$ solution. The improvement on the corrosion resistance was less remarkable in acidic medium. The microhardness of stainless steel slightly improved by $8.7 \%$ compared with that of the as-received metal due to the low laser ablation power applied. Hence, we conclude that fibre laser can be used for laser ablation to enhance the corrosion resistance and surface hardness of steel.

\section{Acknowledgement}

This work was substantially supported by the Universiti Kebangsaan Malaysia (GGPM-2016-054 \& GGPM-2017043). The authors are grateful to the Center for Research and Instrumentation, UKM for the support on the X-ray diffraction (XRD) characterisation of metal plate. The authors would like to thank Amrec Sirim Berhad for the support on the Vicker's Hardness Test.

\section{References}

1. Figueira, R., Silva, C. J. and Pereira, E. (2015). Organic-inorganic hybrid sol-gel coatings for metal corrosion protection: A review of recent progress. Journal of Coatings Technology and Research, 12(1): 1-35.

2. Chen, X., Li, X., Du, C. and Cheng, Y. (2009). Effect of cathodic protection on corrosion of pipeline steel under disbonded coating. Corrosion Science, 51(9): 2242-2245.

3. Musa, A. Y., Kadhum, A. A. H., Mohamad, A. B., Daud, A. R., Takriff, M. S., Kamarudin, S. K., and Muhamad, N. (2009). Stability of layer forming for corrosion inhibitor on mild steel surface under hydrodynamic conditions. International Journal Electrochemical Science, 4: 707-716.

4. Aparicio, M., Jitianu, A., Rodriguez, G. Degnah, A., Al-Marzoki, K., Mosa, J. and Klein, L.C. (2016). Corrosion protection of AISI 304 stainless steel with melting gel coatings. Electrochimica Acta, 202: 325-332.

5. Chong, P. H., Liu, Z., Wang, X. Y. and Skeldon, P. (2004). Pitting corrosion behaviour of large area laser surface treated 304L stainless-steel. Thin Solid Films, 453-454: 388-393.

6. Khalfaoui, W., Valerio, E., Masse, J. E. and Autric, M. (2010). Excimer laser treatment of ZE41 magnesium alloy for corrosion resistance and microhardness improvement. Optics and Lasers in Engineering, 48(9): 926931. 
7. Sun, G., Zhang, Y., Zhang, M., Zhou, R., Wang, K., Liu, C. and Luo, K. (2014). Microstructure and corrosion characteristics of 304 stainless steel laser-alloyed with $\mathrm{Cr}-\mathrm{CrB}_{2}$. Applied Surface Science, 295: 94-107.

8. Yue, T. M., Yu, J. K., Mei, Z. and Man, H. C. (2002). Excimer laser surface treatment of Ti-6Al-4V alloy for corrosion resistance enhancement. Materials Letters, 52(3): 206-212.

9. Boutinguiza, M., del Val, J., Riveiro, A., Lusquiños, F., Quintero, F., Comesaña, R. and Pou, J. (2013). Synthesis of titanium oxide nanoparticles by ytterbium fiber laser ablation. Physics Procedia, 41: 787-793.

10. Pacquentin, W., Caron, N. and Oltra, R. (2015). Effect of microstructure and chemical composition on localized corrosion resistance of a AISI 304L stainless steel after nanopulsed-laser surface melting. Applied Surface Science, 356: 561-573.

11. Lawrence, S. K., Adams, D. P., Bahr, D. F. and Moody, N. R. (2016). Environmental resistance of oxide tags fabricated on 304L stainless steel via nanosecond pulsed laser irradiation. Surface and Coatings Technology, 285: 87-97.

12. Ren, Y., Luo, Y., Zhang, K., Zhu, G. and Tan, X. 2008. Lignin terpolymer for corrosion inhibition of mild steel in 10\% hydrochloric acid medium. Corrosion Science, 50: 3147-3153.

13. ASTM E92 Standard Test Method for Vickers Hardness of Metallic Materials. (2015). Access from http://www.wmtr.com/en.astme92.html.

14. El Maghraby, A. A. (2009). Corrosion inhibition of aluminum in hydrochloric acid solution using Potassium Iodate Inhibitor. The Open Corrosion Journal, 2:189-196.

15. Wang, Q.-Y., Wang, X.-Z., Luo, H. and Luo, J.-L. (2016). A study on corrosion behaviors of Ni-Cr-Mo laser coating, 316 stainless steel and X70 steel in simulated solutions with $\mathrm{H} 2 \mathrm{~S}$ and CO2. Surface and Coatings Technology, 291: 250-257.

16. Wang, X.-T., Wei, Q.-Y., Zhang, L., Sun, H.-F., Li, H. and Zhang, Q.-X. (2016). CdTe/TiO 2 nanocomposite material for photogenerated cathodic protection of 304 stainless steel. Materials Science and Engineering: B, 208: 22-28.

17. Musa, A. Y., Kadhum, A. A. H., Mohamad, A. B., Rahoma, A. A. B. and Mesmari, H. (2010). Electrochemical and quantum chemical calculations on 4,4-dimethyloxazolidine-2-thione as inhibitor for mild steel corrosion in hydrochloric acid. Journal of Molecular Structure, 969(1-3): 233-237.

18. Hanza, A. P., Naderi, R., Kowsari, E. and Sayebani, M. (2016). Corrosion behavior of mild steel in H2SO4 solution with 1, 4-di [1'-methylene-3'-methyl imidazolium bromide]-benzene as an ionic liquid. Corrosion Science, 107: 96-106.

19. Behpour, M., Ghoreishi, S., Kashani, M. K. and Soltani, N. (2009). Inhibition of 304 stainless steel corrosion in acidic solution by Ferula gumosa (galbanum) extract. Materials and Corrosion, 60(11): 895-898.

20. Shadangi, Y., Chattopadhyay, K., Rai, S. B. and Singh, V. (2015). Effect of LASER shock peening on microstructure, mechanical properties and corrosion behavior of interstitial free steel. Surface and Coatings Technology, 280: 216-224.

21. Lu, J. Z., Qi, H., Luo, K. Y., Luo, M. and Cheng, X. N. (2014). Corrosion behaviour of AISI 304 stainless steel subjected to massive laser shock peening impacts with different pulse energies. Corrosion Science, 80: 53-59.

22. Ait Albrimi, Y., Ait Addi, A., Douch, J., Souto, R. M. and Hamdani, M. (2015). Inhibition of the pitting corrosion of 304 stainless steel in $0.5 \mathrm{M}$ hydrochloric acid solution by heptamolybdate ions. Corrosion Science, 90: 522-528.

23. Song, B., Dong, S., Liu, Q., Liao, H. and Coddet, C. (2014). Vacuum heat treatment of iron parts produced by selective laser melting: Microstructure, residual stress and tensile behavior. Materials \& Design (1980-2015), 54: 727-733.

24. Cui, C., Hu, J., Liu, Y., Gao, K. and Guo, Z. (2008). Morphological and structural characterizations of different oxides formed on the stainless steel by Nd:YAG pulsed laser irradiation. Applied Surface Science, 254(20): 6537-6542.

25. Cui, C., Hu, J., Liu, Y. and Guo, Z. (2008). Microstructure evolution on the surface of stainless steel by Nd:YAG pulsed laser irradiation. Applied Surface Science, 254(11): 3442-3448.

26. Llewellyn, D. and Hudd, R. (1998). Steels: metallurgy and applications: Butterworth-Heinemann.ASTM E92 Standard Test Method for Vickers Hardness of Metallic Materials. (2015). Access from http://www.wmtr.com/ en.astme92.html. 
27. Li, D., Feng, Y., Bai, Z., Zhu, J. and Zheng, M. (2007). Influence of temperature, chloride ions and chromium element on the electronic property of passive film formed on carbon steel in bicarbonate/carbonate buffer solution. Electrochimica Acta, 52(28): 7877-7884.

28. Marcuci, J. R. J., Souza, E. C. d., Camilo, C. C., Di Lorenzo, P. L. and Rollo, J. M. D. d. A. (2014). Corrosion and microstructural characterization of martensitic stainless steels submitted to industrial thermal processes for use in surgical tools. Revista Brasileira de Engenharia Biomédica, 30: 257-264. 